\title{
EXPLORING MBA CAREER SUCCESS
}

\begin{abstract}
Purpose: The paper examines the meaning of career success in relation to the attainment of an MBA degree, for a group of experienced managers. In so doing, the paper considers the adequacy of MBA career success, defined solely in terms of external criteria.
\end{abstract}

Design/Methodology/Approach: 36 in-depth interviews were undertaken with MBA alumni which sought to capture the individual's own account of their career success in relation to their MBA. The study utilised an inductive data analysis approach.

Findings: The findings revealed a diversity of meanings given to MBA career success, with success generally being expressed in much broader terms than conventional notions of fast track career advancement. The salience of internal criteria for judging MBA career success is thus highlighted. The findings may be seen to further dispel the myth that MBA students are concerned exclusively with status and salary.

Research Limitations/Implications: The study focuses on the experiences of graduates from only one MBA programme. Additionally, the study reports retrospective accounts of MBA career success, a longitudinal design would be advantageous.

Practical Implications: The demonstration of a plurality of career success provides potential advantage for business schools recruiting MBA students. Organizations can benefit from a wider understanding of MBA career success.

Originality/value: The findings suggest that the value of the MBA encompasses more than fast track career success.

Keywords: MBA, career success, internal career. 
Paper type: Research paper 


\section{EXPLORING CAREER SUCCESS AND THE MBA}

\section{INTRODUCTION}

A popular conception surrounding the MBA degree is that it leads to fast track career success, typically construed in terms of improved salary and hierarchical position (Baruch and Peiperl, 2000; Carnall, 1992). Indeed, the value of the MBA is often questioned when such career benefits are not found (Pffefer and Fong, 2002). However, this may be seen to represent a somewhat narrow view of the relationship between the MBA and career success, since the focus is restricted to objective measures. As such, this perspective does not encompass the diverse ways in which individuals may perceive career success. In other words, a consideration of internal career success is neglected.

This neglect is perhaps surprising given changes to career climate. Whilst the demise of the traditional career may be exaggerated in the literature (Guest and MacKenzieDavey, 1996), there is evidence of serious changes in terms of careers offered by organizations (Littler et al., 2003), especially in the case of managers (Cappelli, 1992). Arnold (1997) for example, argues that success defined in terms of hierarchical advancement is now thought to be available to far fewer managers than it was in the past. Given such changes in organizational career structures, it seems curious that the MBA is still judged almost exclusively in terms of progression in hierarchical position and salary increase. 
Further, an external definition of MBA career success may perhaps be seen to be more applicable to the traditional MBA graduate, i.e. the individual with little or no management experience who has undertaken a full time programme, straight from first degree (Mintzberg, 2004). Such a definition may be inadequate to describe success for more experienced managers, who also undertake MBA programmes. Indeed, research suggests that increasingly, those who undertake MBA programmes have significant managerial experience (Merritt, 2004). Such managers are likely to be at various points in their career development, and research has shown that definitions of success change over the individual's lifespan with external criteria for career success becoming of less importance (Sturges, 1999).

The divergence between MBA career success and insights generated from career theory, both in terms of career climate and career development, reflect a broader contradiction between career theory and career success research more generally with Arthur et al. (2005 p.193) arguing that the two are "considerably out of step with one another". They call for rapprochement and in particular, greater consideration of internal career success. The paper here examines the meaning of career success in relation to the attainment of an MBA degree for a group of experienced managers. In so doing, the paper considers the adequacy of MBA career success defined solely in terms of external criteria. The study informs and extends the existing literature on MBA career success, by offering a broader consideration of success than has previously been found. 


\section{The External Career}

The literature has long differentiated between the external and the internal career, and accordingly, external and internal measures of career success (Melamed, 1996; Poole et al., 1993; Schein and Van Maanen, 1977). However, there has been a tendency in the literature to give more attention to the external career (Arthur and Rousseau, 1996; Hall, 2002). Schein and Van Maanen (1977) define the external career as a sequence of official positions, salary changes, formal structures and titles, all of which are publicly accessible and defined external to the person. External or objective career success is therefore measured in terms of society's evaluation of achievement with reference to extrinsic measures, such as salary and managerial level (Melamed, 1996).

Consistent with the wider career literature's tendency to focus more on the external career, career success in relation to the attainment of an MBA degree is primarily conceptualised in terms of the external career. Accordingly, research which examines the impact of the MBA degree commonly includes measures of salary and hierarchical position of the MBA graduate. The findings from such studies are somewhat equivocal. Pfeffer (1977) and Thomson et al. (1998) have found evidence that the MBA provides a one off salary increase at the end of study rather than a continued salary gain. Others, such as Dugan et al. (1999) suggest that salary increases were only associated with those who had graduated from more prestigious business schools. In respect of hierarchical level, Baruch and Peiperl (2000) found that MBA graduates did not differ significantly from non MBA graduates. Thus in terms of external career success, it would seem that the MBA has limited impact, and as such, adds to the questioning of the value of the MBA degree (Pffefer and Fong 
2002). However, this is to assume that external career success is of sole importance to the MBA degree holder. Research by Sinclair and Hintz (1991) suggested that MBA students held ambitions for personal rather than financial growth, with expansion of opportunities and career flexibility being seen as more important than monetary gain. A broader examination of MBA career success would therefore seem necessary. Such examination could usefully consider the internal career.

\section{The Internal Career}

The internal career has been defined as a person's own subjective idea about work and life, and his or her role within it (Schein and Van Maanen, 1977). Internal career success thus refers to an individual's judgement of their own success (Gattiker and Larwood, 1986), and is frequently defined psychologically in terms of self fulfilment, challenge and satisfaction (Weick and Berlinger, 1989). Internal career success draws on an individual's subjective feelings towards their careers, and thus is also referred to as subjective career success. This has been measured in various ways, for example, through intrinsic indices, such as perceptions of career accomplishments, future prospects (Ayree et al., 1994) and career satisfaction (Cox and Harquil, 1991; Poole et al., 1993).

A consideration of the internal career may be seen to allow a greater variance in the ways in which career success is defined by individuals. From an internal career perspective, success may be seen to include increased autonomy; increased challenge and excitement; balancing work and life commitments (Derr, 1986); growth in competence, affirmation from respected others and opportunities for new learning 
(Weick, 1996). There is thus a suggestion of diverse conceptualisations of career success.

Such diversification may be expected in today’s career climate (Baruch, 2004a). The literature suggests that the traditional career, typified by a continual series of upward moves within a single organization, has been replaced by what Arthur (1994) has termed the 'boundaryless' career in which sideways, inter organizational moves, and employment breaks are typical, and individuals rather than organizations take ownership of careers and responsibility for career development. Whilst the extent to which this shift is evidenced in reality has been questioned (Guest and MacKenzieDavey, 1996), there seems a general acceptance that serious changes have taken place (Ackah and Heaton, 2004, McDonald et al., 2005). Adamson et al. (1998 p.225) argue that "most organizations are now not talking of opportunities for advancement and/ or progression but of opportunities to improve marketability and employability”. Some suggest that in the case of the manager, opportunities for hierarchical advancement are available to far fewer than was the case in the past, owing to the reduction in layers in the organization (Arnold, 1997; Thomas and Dunkerley, 1999). Consequently, it has been suggested that managers need to develop 'career resilience' and to actively manage their careers by enhancing their employability (Waterman et al., 1994). The increased onus on the individual manager is captured in Hall and Moss's (1998) concept of the protean career in which "the person, not the organization, is managing. It consists of all of the person's varied experiences in education, training, working in several organizations, changes in occupational field etc. The protean person's own personal career choices, and the search for self fulfilment, are the unifying or integrating elements in his or her life. The criterion of 
success is internal (psychological success) not external” (p.25). Notably, Reitman and Schneer (2003) in a longitudinal study of MBA graduates found that the majority followed a protean career path. An increased emphasis on the internal career is therefore highlighted.

Whilst recent changes in career structures signify a need for a broader examination of career success, the literature also suggests, that conceptions of success may generally be more dynamic than are traditionally presented. For example, research by Sturges (1999) identified that managers' conceptions of career success varied with age, with older managers less inclined to define success in terms of external criteria. This is consistent with a conceptualisation of career as a developmental process that comprises several stages such as Super's (1980) life-span, life-space theory which acknowledges changes in the individual's vocational preferences as the individual passes through various life stages. It follows, therefore, that success may be defined in different ways at various times in the individual's life. Other research has also identified gender differences in the way success is conceptualised with women placing more emphasis on internal career success (Keys, 1985; Simpson, 2000; Sturges et al., 2003). Such variation in the way career success is defined, suggests a need for a more inclusive examination of success in relation to the MBA degree. Indeed, work by Sturges et al. (2003) involved a broader examination of MBA career success than has been found in previous studies and highlighted that the MBA was seen to develop 'knowing-why' 'knowing-how' and 'knowing-whom' career competencies, illustrating a variety of ways in which the MBA facilitated career success. 


\section{The present study}

The present study sought to address the rather narrow ways in which MBA career success has so far been conceptualised, and in turn researched. The study was interested in building a more inclusive understanding of career success in relation to the attainment of the MBA degree, reflecting changes in the nature of careers, and also the recognition that MBA career success may not necessarily be conceptualised in external terms by experienced managers. To facilitate such an understanding, it was also felt important to ascertain managers’ reasons for undertaking the MBA degree. Broadly, two key research questions were addressed:

RQ1 What reasons do managers provide for taking an MBA degree?

RQ2 How do managers describe their career success in relation to the attainment of their MBA degree?

\section{Research Context}

The study was conducted at a large UK university, whose business school is rated in the top 15 business schools in the UK (Guardian, 2004). The focus of this study was the school's part time MBA programme which is aimed at existing or aspiring senior managers, and thus the participants in this study were those already in management positions. 


\section{Method}

The study adopted an interpretive approach which sought to capture the individual's own account of their career success in relation to their MBA studies. An interpretive approach is concerned with developing an understanding of the meanings individuals attach to experienced phenomena (Denzin and Lincoln 2000) which was seen to be appropriate here, given the focus on the internal career, and our underdeveloped understanding of the ways in which the MBA may relate to career success. Most research which has investigated career success and the MBA, and indeed career success in general, has tended to adopt a positivist approach. Such research employs quantitative methods which may not be most appropriate for understanding the diverse ways in which career success is conceptualised, since such an approach necessarily predefines the dimensions of success (Gunz and Heslin, 2005). Indeed, Arthur et al. (2005, p.196) argue that "the overall body of empirical work on career success seems to be clearly lacking in qualitative input. How can subjective careers be adequately researched when the subjective interpretations of the career actors themselves - apart from their non-verbal responses to a limited set of questionnaire items - are not allowed expression?” Moreover, the interpretive work undertaken by Sturges et al. (2003) has identified diverse ways in which the MBA is seen to relate to the career suggesting a need for further work of this kind.

Thirty six in-depth interviews were conducted with MBA alumni of the university: 20 men and 16 women, aged between 29 and 56, who graduated between 1993 and 2004. The majority of those interviewed were in their thirties when completing their MBA, 
and as dictated by entry requirements, all had a minimum of three to four years managerial work experience, most with significantly more. Those interviewed came from a variety of job backgrounds spanning private, public and voluntary sectors, in various managerial positions, ranging from middle managers to board directors. As is commonly found in qualitative research studies, purposive sampling was used which enabled the use of judgement to select cases which best helped in answering the research questions (Miles and Huberman, 1994). Each interview lasted between 1 and 2 hours, and took place at either the manager's place of work, or at the university business school. The interviews were semi-structured, and managers were asked to describe their careers to date, their MBA experience and what the MBA was seen to mean for their career. Asking managers to describe their MBA career success in broad terms, thus allowed an opportunity to provide individual definitions of success, which may include both internal and external criteria. The literature suggests that whilst the internal criteria may be of increasing significance, the influence of external criteria is acknowledged (Gattiker and Larwood, 1989).

The interviews were digitally recorded and fully transcribed. The study utilised an inductive approach to data analysis, consistent with the concept of grounded theory (Strauss and Corbin, 1998). Given the underdeveloped understanding of MBA career success, an inductive approach was felt to be more sensitive to unanticipated outcomes. Data analysis followed guidelines developed by Strauss and Corbin (1998). Initially, an open coding process was employed through reading and re-reading interview transcripts, allowing concepts to emerge from the findings. Emerging concepts were given codes and then organised into possible categories. Earlier analysis informed subsequent data collection allowing further exploration and 
refinement of existing categories and their relationships. New categories were added as the data collection continued and sometimes existing categories were amended or deleted in the light of later findings. For example, a category 'career commitment' was later subsumed into the category 'career climbing'. The data analysis thus involved an iterative process moving between data collection and data analysis. In the generation of categories, the frequency, salience and consequence to individuals were taken into account. At various points in the study, emerging concepts were discussed with academic colleagues to provide fresh insight to promote an enhanced openness to the analysis. The influence of the researchers on the analysis should be acknowledged here. As Watson (1994, p79) argues "management researchers select, interpret, colour, emphasize, shape their findings. But they do not invent say, the machines they write about or the experiences of redundancy of the people they interview". The findings that follow thus represent our constructed understanding of how managers' perceived their MBA in relation to their careers.

\section{FINDINGS}

The interviews generally suggested a more complex picture of the MBA in relation to the career than is ordinarily assumed. Of interest, the reasons managers gave for pursuing the MBA degree were more diverse than a focus on career promotion. Whilst this was important for some, motivations such as knowledge development, personal challenge and enhanced employability were more frequently emphasised (see table I). In considering career movement since the MBA, the interviews also revealed interesting findings. In contrast to the common suggestion of 'careerist' attitudes of MBAs (Dougherty et al., 1993), nearly two thirds of the sample here 
remained in the same organisation (see table II). These findings may also be seen to indicate the co-existence of protean and promised career paths and lend support to Reitman and Schneer (2003). However, even for those who remained in the same organization, there was a suggestion of diverse patterns, including stability, upward and sideways moves. Against such a background, definitions of MBA career success become more complex.

\section{Take in table I and II}

The analysis revealed a number of ways in which the MBA was seen to relate to careers, with the interviews providing rich accounts of the meaning of MBA career success in managers' own words. A traditional definition of MBA career success was generally inadequate to explain the relationship between the MBA and career for many managers. Instead, managers tended to define their MBA career success in terms of internal criteria, suggesting that the MBA was seen to enhance 'career confidence' and 'career choice'. Whilst the MBA was seen to have a positive relationship with the manager's career, the analysis also identified several instances where the MBA was perceived to be detrimental to career success. It should be noted here, that managers often described their success in various ways, but tended to emphasise a particular form of success. Table III illustrates the ways in which managers described their MBA in relation to their career success.

Take in table III 


\section{Career climbing}

Conventional definitions of MBA career success tied to external criteria, such as position and salary, were identified as important for nine of the managers interviewed and tended to be provided by male managers and younger female managers (6 males, aged 32-47 years; 3 females aged 31-37 years). The identified importance of career climbing to younger managers is broadly consistent with the career stages identified by Super (1980) which suggest that between the ages of 25-45 a key concern is advancing in one’s position. However, even when MBA career success was described in such terms, some questioned the causal nature of the relationship between the MBA degree and career success, suggesting that the relationship may be more complex than is widely presented.

"Well did it help my career? Well, you would have to analyse [but] there is no doubt that there is a correlation between people who did the MBA and where they got to in the organization. But then you know attribution theory: is that because of them, or is it because of the organization, or is it because they were good people anyway, and you know good people perform well”. [Male, 39, 1997 graduate]

Further, a number of managers expressed a belief that the MBA degree would in the future enhance their promotion opportunities, but felt this may be attributable to the commitment to career, that MBA study was seen to represent, in the case of the part time student rather than any perceived value peculiar to the MBA. 
“I don't know where it will take me, it has not done me any harm from a career point of view, if I wanted to move on it can't do me any harm that I have undertaken a professional qualification and shown the commitment to pass it. Employers may not give any credence to an MBA, I don't know, but it shows more that you have got the commitment to go and do something”. [Female, 33, 2001 graduate]

Several of the managers explicitly rejected a conceptualisation of MBA career success in terms of career climbing:

“Well I mean career wise, I am not looking for promotions. I am very happy doing what I am doing. I am learning lots. I mean, if I lost my job now, only then would I look for another job, but I would probably be tempted to try and set up on my own rather than work for somebody else. So job wise, I am not using it personally as a leverage, now I am 41, go back ten years if I was 31 then I might say it's quite important for job progression, but for me I have never really been career minded because you know I wanted to do other things. So I don't really look at it as a career tool”. [Male, 41, 2001, graduate]

“In terms of success, in terms of are you now a managing director of $x$ department, in an international organization, the answer is 'no', but I don't think that has got anything to do with whether I did an MBA or not, it's to do with the fact that I don't want to be the chief executive of a multi national business”. [Female, 44, 1999 graduate] 
For the two managers here, there would seem to be little value attached to hierarchical career progression, instead enjoyment of the job and learning opportunities are valued.

\section{Career Confidence}

The analysis demonstrated that internal definitions of MBA career success were salient for over two thirds of the sample. The most common internal criteria for success, related to what may be described as career confidence with 19 managers describing their MBA career success in such terms (11 males aged 32-43 years; 8 females aged 29-46 years). Career confidence seemed equally important for male and female managers and younger and older managers. Arguably, career confidence would appear to be salient as individuals attempt to establish themselves in their careers (Super, 1980). Personal growth in terms of increased self confidence, self esteem and personal credibility taken from the MBA was highly valued. The analysis identified several ways in which career confidence was manifest. For some, enhanced confidence meant that they felt more comfortable and competent in their present role which was seen as an internal indication of career success. The following response illustrates how success is defined in terms of feeling comfortable in the current role, feeling that one is doing a good job rather than being concerned with increased status and salary:

"I think that you have to know your own abilities but sometimes, you have to stretch yourself to know what they are and to have confidence in yourself. You know at first when you go into a managing role, you are quite nervous by the whole process of 
leading people and think, I am not going to be very good at this. I think it is having confidence in your own abilities, and knowing what you are capable of doing, and not taking on a role that puts you totally out of your depth because that would make you unhappy... it is no good moving up to a level where there is a great salary, great status position, but you can't handle it because the pressure is too great and the stress is too great"”. [Female, 32, 2004 graduate]

Increased confidence was also seen to allow the manager to take on new challenges and responsibilities in their organizations which previously they would have avoided.

"It has helped me at both a personal and a professional level. I think it has really untapped something, I always believed that I had the potential but I was never quite, totally comfortable with myself, and now I feel as though the MBA has given me the platform to say actually 'yeah', I have developed that potential”. [Male, 35, 2003 graduate].

Of interest, although in some cases this may have meant an upwards move, it was the increased confidence to perform their roles and suggestion of personal growth which was emphasised rather than hierarchical advancement. For some, the increased confidence developed during the MBA programme was associated with a perception of enhanced employability. Managers suggested that they were less anxious about the future job market as they felt that their personal development on the MBA programme would prove beneficial to future career moves. 
"I am more confident in my own abilities now, and I am quite happy to take redundancy, and go out there and see what is going to happen, whereas before I would have been worried”. [Female, 39, 2003 graduate]

\section{Career Choice}

Consistent with the decreased importance placed on external criteria, 15 managers described MBA career success in terms of increased choice, flexibility and opportunity with such success tending to be particularly salient for female managers (11 females aged 29-49 years; 4 males aged 35-56 years). It was also evident, that success defined in terms of choice, was salient for both the younger and older manager which is consistent with changes in the nature of careers generally. This is perhaps more problematic for Super’s (1980) theory, since choice may be seen to be most significant in the later continuity stage, where the individual potentially makes a transition to a different occupation. As Baruch (2004b) highlights, Super’s stages may not be fully representative of today’s career climate.

Choice was described in various ways, in several cases; the MBA was seen to facilitate lateral career moves: one manager described this as 'hopping between lily pads' rather than stepping up. Such moves were seen to allow the manager to enter new areas, for example, to move from the private sector to the public sector, and also lateral career moves within the organization which were seen to provide increased enjoyment and variety to the career. For others, the breadth of opportunities seen to be facilitated by the MBA were important in allowing greater career flexibility. Both the 
skills developed by the MBA and the MBA qualification itself were seen to improve the individual's marketability thus allowing an increased control over the career.

"I have never had a kind of career path in mind, so I don't have this thing of you know, expecting to be with one organization, expecting to be with a particular role... but I thought if I have the skill set and the bits of paper, then the chances were I could do pretty much what I wanted to do”. [Female, 44, 1999 graduate]

Indeed, this individual has made several inter organizational moves since the completion of the MBA. For several managers, the MBA was seen to provide enhanced career choice by allowing the manager the opportunity to remain in valued career positions. This was particularly the case where the manager valued work-life balance.

“The MBA has probably meant that I have kept the job. It hasn't meant anything else because I haven't used it in an attempt to go and search for another role. Now one of the reasons for that, is that I didn't particularly want to move to another location... work life balance has always been very important to me, and I will also say that if I go back to my earlier times, then work was something that I had to do to run a home and a family, but it wasn't where I got my kicks, you know. And it is still very much the same; I mean I still do lots of things outside of here which are important to me”. [Male, 56, 1999 graduate]

Thus for this manager MBA career success was described in terms of the maintenance of a balance between work and life activities. This individual did not value career 
moves which would jeopardise this, and thus his MBA was perceived as successful in terms of his career, since it was seen to secure his present position. There is some evidence here, that MBA career success is defined in terms of employability providing the choice to move between organizations and industries, and in some cases, the choice to remain in the present organization. For managers who define MBA career success in terms of enhanced choice, measures of internal career success are thus significant.

\section{Career Detriment}

Whilst on the whole managers perceived their MBA to have positive implications for their career success, seven managers suggested that the MBA could have detrimental effects (5 males aged 33-43 years; 2 females aged 45-49 years). An important distinction was made here, between the MBA as a qualification and the MBA as a learning experience. Where the MBA was seen to be detrimental to career success, this related to the MBA as a qualification. This is illustrated below:

“The MBA has taught me stuff that I didn't know, as simple as that, but the qualification itself hasn't done anything for me...in this place qualifications count for nothing”. [Male, 34, 2003 graduate]

Further, some managers suggested that they had encountered a resistance to their qualification when applying for new jobs, both internal and external to the organization. It was suggested that others could sometimes be opposed to the 
qualification, especially where the potential employer did not hold an MBA degree themselves and questioned the value of management education.

"You do get a significant minority of people who think that college is all poppycock and it is the university of hard knocks, that is where you need to learn, and a management qualification is a waste of time because it doesn't teach you how to be a manager”. [Male, 33, 2004 graduate]

Some suggested that owing to this resistance, they had to make a judgement about whether or not to include their MBA qualification on their CVs. Thus it would seem that in some cases the MBA letters may serve to hinder career success in terms of career moves. However, this did not detract from the intrinsic career value which these managers had taken from their MBA programme. Indeed, managers emphasised the importance of their MBA learning experience over the MBA qualification:

"I think the real advantage would not be having the MBA letters just more about the sort of more qualitative difference it makes to you in terms of how you are”. [Male, 33, 2004 graduate]

Thus both internal and external dimensions to MBA career success are identified here, with managers placing greater value on internal dimensions. 


\section{DISCUSSION}

The findings revealed a diversity of meanings given to MBA career success. Career success in relation to the MBA degree, was generally expressed in much broader terms than conventional notions of fast track career advancement, reflecting the diversity of reasons for pursuing the degree. The salience of internal criteria for judging MBA career success is thus highlighted. The findings may be seen to further dispel the myth identified by Sinclair and Hintz (1991) that MBA students are concerned exclusively with status and salary.

Contrary to popular belief, a definition of MBA career success which included a focus on external measures was only provided by a small number of managers. MBA career success described in these terms tended to be provided by male managers and younger female managers, and thus supports earlier research by Sturges (1999) which likewise suggested that external success criteria are more important to males and younger managers. Therefore, MBA career success defined solely in terms of external criteria alone would not seem to be applicable to all MBA graduates. This could be interpreted to mean that traditional career advancement does not necessarily follow the attainment of an MBA degree, and thus be seen to support previous work which suggests that the MBA has a limited impact on careers (Dugan et al., 1999; Thomson et al., 1998). It could be that individuals who have invested time and money in the degree are forced to construct alternative notions of success. However, this is inconsistent with managers' descriptions of their careers to date which generally lacked ambition along the lines of traditional career climbing, with managers often explicitly suggesting that they had 'no career path in mind', and reasons for pursuing 
the MBA which often related to personal challenge and development rather than hierarchical advancement and monetary gain: "For me it was a personal thing, it had nothing to do with climbing up the slippery pole at work"” [Male, 43, 2000 graduate].

Instead, career success was defined more frequently in terms of the internal career. This adds support to Sturges (1999) by demonstrating the importance of internal career success amongst a sample of MBA managers who traditionally are thought to emphasise external dimensions of success. The research identified that career success was often defined in terms of increased confidence and career choice, and thus the MBA may be seen to make a qualitative difference to the manager's career rather than a quantitative improvement. Notably, in several cases where managers had made upward career moves, it was the confidence to make these moves which was emphasised, rather than the hierarchical advancement. Of interest, whilst it has been noted that male managers were more likely to offer external definitions of success, many males also emphasised internal career benefits, which differs from earlier research, which found internal career benefits were generally of much less importance to male MBAs (Simpson, 2000).

The development of increased career confidence was the most common way in which the MBA was seen to relate to career success which often related to a feeling of increased competence in the current role. This is consistent with Sturges's (1999) identification of 'experts'. 'Experts' were managers who described career success in terms of achieving a high level of competency in their job, and being recognised for being good at what they did. The value of increased self confidence taken from the MBA was also suggested by Sturges et al. (2003) and Hilgert (1998) and these studies 
taken together suggest that self confidence would seem to be especially significant in terms of MBA career success.

Increased career choice was also an important way in which the managers defined their MBA career success. This related to broadening and opening up of new opportunities for the manager, and allowing managers to make career choices which they valued, which in some cases, meant remaining in the present role. It would seem that the MBA perhaps facilitates an increased control over the managerial career, demonstrating a form of career resilience (Waterman et al., 1994), and may be seen as highly valuable in today's uncertain career climate.

Of interest, both career confidence and career choice may be seen to be associated with stability and movement. The confidence taken from the MBA for some, meant staying in their present roles but feeling more competent, and for others, the confidence to move to new positions. Similarly, with respect to career choice, some valued the choice to move to a variety of new jobs, whilst others highly regarded the choice to remain in the same role. Thus success can be construed both in terms of stability and movement, yet success is popularly perceived in terms of movement. Indeed, a number of the managers suggested that their MBA career success may be questioned by some, as they had not moved positions, but strongly suggested that this did not detract from their success defined in their own terms. It would seem that the relationship between the MBA and the career is more complex than is traditionally portrayed, and can be seen to encompass stability as well as movement. 
It is also important to acknowledge the perceived detrimental effect of the MBA in a small number of cases. Notably, this did not relate to the intrinsic value of the MBA but to external perceptions of its worth. This highlights the importance of employer perceptions of the MBA which often seem to be neglected when debating the career worth of the MBA. The suggestion of career detriment further illustrates the existence of internal and external dimensions of MBA career success, and suggests caution in judging the value of the MBA in terms of external criteria alone. It would seem that in many ways, where the MBA is described in terms of a qualification, this relates to the external career, and where the MBA is described in terms of a learning experience, this relates more closely to the internal career. Indeed, it is encouraging that managers emphasise the MBA in terms of the learning experience given recent concerns of exclusive focus on certification for career promotion (Pfeffer and Fong, 2004). As Mintzberg (2004) argues, the career worth of an MBA can be significant for those managers who have several years work experience, and thus employers may need to question their assumptions towards the MBA, at least in respect of this group.

\section{Implications}

The study has a number of implications for both management education and organizations. In respect of management education, those responsible for student recruitment may acknowledge the diversity in notions of career success: programmes which are marketed exclusively in terms of fast track success may not resonate with all potential students. The demonstration of a plurality of career success may also provide a potential advantage for business schools competing in increasingly tight MBA markets. Organizations can likewise benefit from a wider understanding of 
MBA career success. The study has shown that the MBA is seldom perceived in terms of a fast track ticket, perhaps reflecting more grounded expectations of an MBA education, and thus the MBA degree does not necessarily represent a threat to organizational retention. Of note, nearly two thirds of the sample here remained with the same organization. Further, there is evidence of the benefit to organizations, through, for example, increased confidence to perform and willingness to tackle new responsibilities. The findings also suggest alternative ways in which organizations may contribute to the career success of the individual beyond hierarchical advancement, which as noted, may be increasingly difficult for organizations to offer, especially in the case of managers. For example, organizations may provide development opportunities which enhance feelings of confidence in job performance.

\section{Limitations and future research}

Whilst the study provides a broader understanding of MBA career success, work is needed to develop the categories of career success suggested. The category of career confidence for example, lends itself to investigation from a social cognitive career theory perspective (Lent et al., 1994). An obvious limitation of the study is its focus on the experiences of graduates from only one MBA programme. It may be interesting to undertake similar work with more traditional MBA graduates, to ascertain the importance of external and internal measures of success for this group. Whilst the work here can be seen as indicative of the complexity of MBA career success, both the cross sectional and retrospective nature of the study presents difficulties in ascertaining clear patterns. Accordingly, future work may consider a longitudinal design which would allow the researcher to capture changes in notions of 
career success as the individual progresses through the MBA programme and beyond. With respect to career success more generally, the study suggests the importance of research which invites the subjective interpretations of career actors themselves. Such interpretations can provide fresh insights into meanings of success in contemporary career climates. Subjective interpretations also open up possibilities of understanding the ways in which success relates to broader life circumstances, which as Super (1980) highlights, is significant; however further work is needed to capture the dynamic ways in which careers relate to contemporary life circumstances. Future research may also consider broader notions of success to include negative as well as positive elements.

In conclusion, this research adds to the small number of studies which have considered internal career success. The work here suggests that career success in relation to the MBA degree is mainly described in terms which relate to the internal career. This, therefore, suggests that the value of the MBA encompasses more than fast track career success. 


\section{References}

Ackah, C. and Heaton, N. (2004), “The reality of “new” careers for men and women”, Journal of European Industrial Training, Vol.28 No. 2/3/4, pp.141-158.

Adamson, S.J., Doherty, N. and Viney, C. (1998), “The meaning of career revisited: implications for theory and practice”, British Journal of Management, Vol. 9 No.4, pp.251-60.

Arnold, J. (1997), Managing Careers into the $21^{\text {st }}$ Century. London: Paul Chapman.

Arthur, M.B. (1994) “The boundaryless career”, Journal of Organizational Behaviour, Vol.15 No.4, pp. 7-22.

Arthur, M.B. and Rousseau, D.M. (1996), The Boundaryless Career: A New Employment Principle for a New Organizational Era. Oxford: Oxford University Press.

Arthur, M.B., Khapova, S.N. and Wilderom, C. (2005), "Career success in a boundaryless career world”, Journal of Organizational Behaviour, Vol. 26, pp.177202.

Ayree, S., Chay, Y.W. and Tan, H.H. (1994), “An examination of the antecedents of subjective career success among a managerial sample in Singapore”, Human Relations, Vol. 47 No. 5, pp.487-509. 
Baruch, Y. (2004a), “Transforming careers: from linear to multidirectional career paths. Organizational and individual perspectives”, Career Development International, Vol. 9 No.1, pp.58-73.

Baruch, Y. (2004b), Managing Careers. Theory and Practice. Harlow: Pearson.

Baruch, Y. and Peiperl, M. (2000), “The impact of an MBA on graduate careers”, Human Resource Management Journal, Vol.10, pp.69-90.

Cappelli, P. (1992), “Examining managerial displacement”, Academy of Management Journal, Vol.35, pp.203-217.

Carnall, C.A. (1992), MBA Futures. Basingstoke: Macmillan

Cox, T. and Harquil, C. (1991), "Career paths and career success in early career stages of male and female MBAs”, Journal of Vocational Behaviour, Vol.39, pp.5475.

Denzin, N.K., and Lincoln, Y.S. (Eds.) (2000). Handbook of Qualitative Research, ( $2^{\text {nd }}$ ed.). London: Sage.

Derr, C.B. (1986), Managing the New Careerists. San Francisco: Jossey Bass. 
Dougherty, T.W., Dreher, G.F. and Whitely, W. (1993), “The MBA as careerist: an analysis of early career job change”, Journal of Management, Vol.19 No.3, pp.535548.

Dugan, M., Grady, W., Payn, B. and Johnson, T. (1999), “The benefits of an MBA: a comparison of graduates and non-graduates”, Selections, Vol.15 No.2,

Gattiker, U. and Larwood, L. (1986), “ Subjective career success: a study of managers and support personnel”, Journal of Business and Psychology, Vol.1, pp.78-94.

Gattiker, U. and Larwood, L. (1989), "Career success, mobility and extrinsic satisfaction of corporate managers”, The Social Science Journal, Vol.26, pp.75-92.

Guardian, (2004). University Guide.

(http://education.guardian.co.uk/universityguide2004).

Guest, D. and MacKenzie-Davey, K. (1996), “Don’t write off the traditional career”, People Management, February $22^{\text {nd }}$ pp.22-5.

Gunz, H.P. and Heslin, P.A. (2005), "Reconceptualising career success”, Journal of Organizational Behaviour, Vol.26, pp.105-111.

Hall, D.T. (2002), Careers In and Out of Organizations. Thousand Oaks: Sage. 
Hall, D.T and Moss, J.E. (1998), “The new protean career contract”, Organizational Dynamics, Winter, pp.22-38.

Hilgert, A,D. (1998), "Professional development of women and the executive MBA”, Journal of Management Development, Vol.17 No.9, pp.629-643.

Keys, D.E. (1985), “Gender, sex role and career decision making of certified accountants”, Sex Roles, Vol.13 No.2, pp.33-46.

Lent, R.W., Brown, S.D. and Hackett, G. (1994), “Toward a unifying social cognitive theory of career and academic interest, choice and performance”, Journal of Vocational Behaviour, Vol. 45, pp.79-122.

Littler, C., Wiesner, R. and Dunford, R. (2003), “The dynamics of delayering: changing management structures in three countries”, Journal of Management Studies, Vol. 40, No. 2, pp. 225-256.

McDonald, P., Brown, K. and Bradley, L. (2005), "Have traditional career paths given way to protean ones? Evidence from senior managers in the Australian public sector”, Career Development International, Vol.10 No.2, pp.109-129.

Melamed, T. (1996), “Career success: an assessment of a gender specific model”, Journal of Occupational and Organizational Psychology, Vol. 69 No.3, pp.217-42.

Merritt, J. (2004), “Masters of Barely Anything?”, Business Week, Issue.3891, pp.22. 
Miles, M.B., and Huberman, A.M. (1994), Qualitative Data Analysis: An Expanded Sourcebook. London: Sage.

Mintzberg, H. (2004), Managers not MBAs: A Hard Look at the Soft Practice of Managing and Management Development. Harlow: Pearson.

Poole, M., Langan-Fox, J. and Omodei, M. (1993). “Contrasting subjective and objective criteria as determinants of perceived career success: a longitudinal study”, Journal of Occupational and Organizational Psychology, Vol.66, pp.39-54.

Pfeffer, J. (1977), “Effects of an MBA and socioeconomic origins on business school graduates’ salaries”, Journal of Applied Psychology, Vol.62, pp.698-705.

Pfeffer, J., and Fong, C. (2002), “The End of Business Schools? Less Success than meets the eye”, Academy of Management Learning and Education, Vol.1, pp.78-95.

Pfeffer, J. and Fong, C. (2004), “The business school "business”: some lessons from the US experience”, Journal of Management Studies, Vol.41 No.8, pp.1501-20.

Reitman, F. and Schneer, J.A. (2003), “The promised path: a longitudinal study of managerial careers”, Journal of Managerial Psychology, Vol. 18 No.1, pp.60-75.

Schein, E.H. and Van Maanen, J. (1977), Career development. In J.R. Hackman and J.L. Suttle (Eds.), Improving Life at Work. Santa Monica: Goodyear, pp.30-95. 
Simpson, R. (2000), “A voyage to discovery or a fact track to success: men, women and the MBA”, Journal of Management Development, Vol.19 No.9, pp.764-782.

Sinclair, A. and Hintz, P. (1991), "Developing managers: re-examining ten myths about MBAs and managers”, Journal of Management Development, Vol.10, pp.53-65.

Strauss, A. and Corbin, J. (1998), Basics of Qualitative Research: Grounded Theory Procedures and Techniques, 2nd Edition. London: Sage.

Sturges, J. (1999), "What it means to succeed: personal conceptions of career success held by male and female managers at different ages”, British Journal of Management, Vol. 10, pp.239-252.

Sturges, J., Simpson, R. and Altman, Y. (2003), "Capitalising on learning: an exploration of the MBA as a vehicle for developing career opportunities", International Journal of Training and Development, Vol.7 No.1, pp.53-66.

Super, D. (1980), “A life-span, life approach to career development”, Journal of Vocational Behaviour, Vol. 16, pp.282-298.

Thomas, R. and Dunkerley, D. (1999), ““Middle managers’ experiences in downsized organizations”, British Journal of Management, Vol. 10 No.2, pp.157-69. 
Thomson, A., Storey, J., Mabey, C., Thomson, R., Gray, C. and Farmer, E. (1998), Management Development. The Views of the membership of the Association of MBAs. London: AMBA.

Waterman, R.H. Jnr, Waterman, J.A. and Collard, B.A. (1994), “Towards a career resilient workforce”, Harvard Business Review, Vol.76, March-April, pp.87-95.

Watson, T.J. (1994), "Managing, crafting and researching: words, skill and imagination in shaping management research”, British Journal of Management, Vol.5, pp.S77-S87.

Weick, K.E. (1996). Enactment and the boundaryless career: organizing as we work. In M.B. Arthur and D.M. Rousseau (Eds.), The Boundaryless Career, pp.40-57. New York: Oxford University Press.

Weick, K. and Berlinger, L.R. (1989), Career improvisation in self designing organizations. In M.B. Arthur, D.T. Hall \& B.S. Lawrence (Eds.), Handbook of Career Theory. Cambridge: Cambridge University Press. 
Table I Manager's Reasons for Taking an MBA Degree

\begin{tabular}{|lccc|}
\hline $\begin{array}{l}\text { Reason } \\
\%\end{array}$ & Overall & Male & Female \\
\hline Employability & 52.8 & 55.0 & 50.0 \\
\hline Personal Challenge & 50.0 & 45.0 & 56.3 \\
\hline Knowledge Development & 41.7 & 35.0 & 50.0 \\
\hline Career promotion & 38.9 & 30.0 & 50.0 \\
\hline No first degree & 25.0 & 25.0 & 25.0 \\
\hline
\end{tabular}

Table II Career Movement Patterns of MBA Graduates

\begin{tabular}{|lllllll|}
\hline $\begin{array}{l}\text { Career } \\
\text { Movement } \\
\text { \% }\end{array}$ & Overall & Male & Female & $\begin{array}{l}\text { Graduated } \\
\mathbf{1 9 9 3 - 2 0 0 0}\end{array}$ & $\begin{array}{l}\text { Graduated } \\
\mathbf{2 0 0 1 - 2 0 0 2}\end{array}$ & $\begin{array}{l}\text { Graduated } \\
\mathbf{2 0 0 3 - 2 0 0 4}\end{array}$ \\
\hline $\begin{array}{l}\text { New } \\
\text { Internal } \\
\text { Position }\end{array}$ & 36.1 & 30.0 & 43.8 & 13.3 & 42.9 & 57.1 \\
\hline $\begin{array}{l}\text { New } \\
\text { External } \\
\text { Position }\end{array}$ & 36.1 & 40.0 & 31.3 & 73.3 & 14.3 & 7.1 \\
\hline $\begin{array}{l}\text { Same } \\
\text { Position }\end{array}$ & 27.8 & 30.0 & 25.0 & 13.3 & 42.9 & 35.7 \\
\hline
\end{tabular}




\begin{tabular}{|c|c|c|}
\hline $\begin{array}{l}\text { MBA and career } \\
\text { success }\end{array}$ & Description & Examples \\
\hline Career climbing & $\begin{array}{l}\text { Describes MBA career success in } \\
\text { conventional terms, such as } \\
\text { promotion and salary increases. }\end{array}$ & $\begin{array}{l}\text { "It has probably speeded up how fast I have got promotion, that is a useful thing to say. I mean } \\
\text { there is a huge age difference between me and the next senior management team member"”. } \\
\text { [Female, 31, } 2001 \text { graduate] } \\
\text { "Where it has certainly benefited me without any doubt is in getting the jobs that I have got. It does } \\
\text { look very good on your CV, and if you are being interviewed by somebody who also has a MBA, } \\
\text { they really value it, really value it, my boss has one and without any doubt, it opens doors. It looked } \\
\text { bloody great that I was less than } 30 \text { and I had a MBA, this guy is some kind of rising star. I think it } \\
\text { has certainly been a lubricant in my career path. I have been pretty successful, since I have joined } \\
\text { the MBA, I have been promoted one, two, three, four times". [Male, 32, } 1999 \text { graduate] } \\
\text { "I think it has been worth, let's calculate it, it has been worth around about } 58 \text { thousand pounds, } \\
\text { which is the difference between what I was earning when I was as assistant director and what I am } \\
\text { earning now. So if you want a figure on it that is what it means to me". [Male, } 47.1999 \text { graduate] } \\
\text { "There will also be a promotion in the near future, so higher pay level, higher pay band. So the } \\
\text { benefits are already there". [Male, 36, } 2004 \text { graduate] }\end{array}$ \\
\hline Career confidence & $\begin{array}{l}\text { Describes MBA career success in } \\
\text { terms of increased self confidence } \\
\text { and personal growth. }\end{array}$ & $\begin{array}{l}\text { "It has given me more confidence, I mean I took on this role as logistics manager two years ago } \\
\text { which meant moving into an area which I knew nothing about. I probably would have been less } \\
\text { confident to have done it. Even though I hadn't finished the MBA, but the fact is that you go through } \\
\text { a pretty intense period of developing yourself, and to me that was part of developing. So it probably } \\
\text { made me feel more confident, I probably wouldn't have applied to take on that extra responsibility } \\
\text { to be honest". [Male, 40, } 2003 \text { graduate] } \\
\text { "I wanted to move [in] my job because I think the first year of the MBA gave me so much } \\
\text { confidence. I met a lot of people there you know, they all came from different backgrounds and } \\
\text { different companies, and I felt that 'look if they are doing this, I can also do it'. So I think that } \\
\text { actually gave me the confidence to make the jump [from a temporary position to a permanent } \\
\text { position]". [Female, 45, } 1999 \text { graduate] }\end{array}$ \\
\hline
\end{tabular}




\begin{tabular}{|c|c|c|}
\hline & & $\begin{array}{l}\text { "I am more confident in my own abilities now, and I am quite happy to take redundancy and go out } \\
\text { there and see what is going to happen. Whereas before I would have been worried, I would have } \\
\text { wanted to know what my next job was. But I am prepared to take that personal risk and that has } \\
\text { come through the MBA, definitely". [Female, 39, } 2003 \text { graduate] } \\
\text { "I believe being able to come onto this project which is hugely important for this organization. I do } \\
\text { feel this huge responsibility, and I do believe that I have shown through the MBA and through what } \\
\text { it has helped me to achieve, that I have the ability and can be trusted with that sort of work". } \\
\text { [Female ,46, } 2001 \text { graduate ] }\end{array}$ \\
\hline Career choice & $\begin{array}{l}\text { Describes MBA career success in } \\
\text { terms of increased flexibility and } \\
\text { opportunity. }\end{array}$ & $\begin{array}{l}\text { "Well, I think it has opened doors, given me career opportunities I wouldn't have had. Given me a } \\
\text { more varied and interesting work life. Given me a work life, that although you have to think hard, I } \\
\text { am not in a physically demanding job which a lot of people are, and tend to be low paid, so I think it } \\
\text { has enabled me to use my brain more I suppose. It gives you a nice lifestyle as a result because you } \\
\text { are working with people, professional people you move in different circles, I suppose". [Female, 49, } \\
1995 \text { graduate] } \\
\text { "I just felt that this would give more opportunity and better job security, and then I have always } \\
\text { worked for choice in life, particularly I think being a female, I choose to work full time and I have } \\
\text { always worked for choices, that is why I have tried to maintain the breadth that is very important to } \\
\text { me in terms of control and being happy. So it has continued to offer me choice and options. I can } \\
\text { either work here, or with the MBA you can work somewhere else, it's a transferable and very } \\
\text { marketable qualification". [Female, } 44,1995 \text { graduate] } \\
\text { "It's provided another step or however you want to look at it, maybe a Lilly pad might be a better } \\
\text { example, being able to hop from one place to another. It opened up horizons and I certainly } \\
\text { couldn't be doing what I am doing now without it, so it has enabled more choice for me and my } \\
\text { career and my life. So it has been significant to me in that regard". [Male, 41, 2001, graduate] } \\
\text { "I think it has opened my views to everything as well, in that I think much bigger than I used to, in } \\
\text { everything. I think bigger in my opportunities, I won't restrict myself to anything I can do. I think I } \\
\text { can do that, if in a couple of years I want to set up my own business, I won't be frightened to do } \\
\text { that". [Female, 38, } 2003 \text { graduate] }\end{array}$ \\
\hline
\end{tabular}




\begin{tabular}{|c|c|c|}
\hline Career detriment & $\begin{array}{l}\text { Describes how MBA qualification is } \\
\text { sometimes perceived to threaten } \\
\text { others and thus hinder career success. }\end{array}$ & $\begin{array}{l}\text { "I did have a foolish notion that once I attached the three little letters to the back end of my name, } \\
\text { that people would be falling over themselves to give me a job. And that has proven not to be the } \\
\text { case. In fact, in some cases it has jeopardised me even getting an interview". [Male, 43, } 2000 \\
\text { graduate] } \\
\text { "It has had quite a negative effect since I have graduated, for that reason I will keep it off my } \\
\text { business card, because it is only worth something to somebody who values it, you see. And it can } \\
\text { have a detrimental effect to somebody who doesn't value it, because they can immediately make } \\
\text { exception to you". [Male, 36, 2003, graduate] } \\
\text { "There is a danger that the MBA can actually threaten people as well. You know you can be } \\
\text { overqualified when you are applying for jobs, and they go' oh MBA'. So it is a double edged } \\
\text { sword". [Female, } 49,1995 \text { graduate] } \\
\text { "There is a downside; people in senior management that knew that I had got the qualification, were } \\
\text { actually threatened by me. And until recently I think it has actually been an impediment to my } \\
\text { career. But that's not from me, that's from other people's perceptions and their inhibitions and } \\
\text { insecurities of whatever. I don't know. But not from me, I feel very comfortable and very happy } \\
\text { internally". [Female, } 45,1995, \text { graduate] }\end{array}$ \\
\hline
\end{tabular}

\section{TABLE III WAYS IN WHICH THE MBA RELATES TO CAREER SUCCESS}


